\title{
Exploring the Traces of Translation and the Cultural Characteristics of Chu Lacquer Wares
}

\author{
Shenghua Luo ${ }^{1,2}$ \& Yinfang Song ${ }^{1}$ \\ ${ }^{1}$ Yangtze University, Hubei, 434020 P. R. China. \\ ${ }^{2}$ Yangtze University College of Arts and Sciences, Hubei, 434020 P. R. China.
}

Type of Work: Peer Reviewed.

DOl: http://dx.doi.org/10.21013/jmss.v15.n4.p5

\section{How to cite this paper:}

Luo, S., Song, Y. (2019). Exploring the Traces of Translation and the Cultural Characteristics of Chu Lacquer Wares. IRA-International Journal of Management \& Social Sciences (ISSN 2455-2267), 15(4), 122-130. doi:http://dx.doi.org/10.21013/jmss.v15.n4.p5

(C) Institute of Research Advances.

\section{(c) B B-NC}

This work is licensed under a Creative Commons Attribution-Non Commercial 4.0 International License subject to a proper citation to the publication source of the work.

Disclaimer: The scholarly papers as reviewed and published by the Institute of Research Advances (IRA) are the views and opinions of their respective authors and are not the views or opinions of the IRA. The IRA disclaims of any harm or loss caused due to the published content to any party.

Institute of Research Advances is an institutional publisher member of Publishers International Linking Association Inc. (PILA-CrossRef), USA. The institute is an institutional signatory to the Budapest Open Access Initiative, Hungary advocating the open-access of scientific and scholarly knowledge. The Institute is a registered content provider under Open Access Initiative Protocol for Metadata Harvesting (OAl-PMH).

The journal is indexed \& included in WorldCat Discovery Service (USA), CrossRef Metadata Search (USA), WorldCat (USA), OCLC (USA), Open J-Gate (India), EZB (Germany) Scilit (Switzerland), Airiti (China), Bielefeld Academic Search Engine (BASE) of Bielefeld University, Germany, PKP Index of Simon Fraser University, Canada. 


\section{ABSTRACT}

As a regional distinctive culture among ancient Chinese civilization, Chu culture was as dominant as it had always been in Chu State during the Spring and Autumn and Warring States period. Among them, Chu lacquer wares are the classic representatives of Chu culture. It is summarized that cultural characteristics refer to the belief, the ornamentation preference, the spirit and the color preference. Thus, these characteristics have a great impact on the corresponding translation of these Chu lacquer wares. Exploring the traces of translation on Chu lacquer wares would boost Chu culture, the outstanding and remarkable treasure of knowledge, and promote cultural exchange.

Keywords: translation; cultural characteristics; Chu lacquer wares

\section{Introduction}

Chu culture is a regional culture with distinctive characteristics in Chinese culture. Moreover, it is well-known for its profound cultural heritage and 800-year-old magnificent history. As a typical representative of Chu culture, the artworks of $\mathrm{Chu}$ lacquer wares condense the infinite wisdom, rich imagination and aesthetic consciousness of $\mathrm{Chu}$ people, reflecting the Chu people's ideology and culture. As early as the 23rd of Universal Postal Union Congress in 2004, China and Romania jointly issued a set of two special stamps "Lacquer ware and Pottery". The motif of the Chinese stamp is the lacquer ware-"DRUM WITH PHOENIX STANDS" unearthed from Jingzhou, which has become an international card of the cultural relic for the first time. In response to the policies from the Chinese government: cooperative development concept_ “One Belt and One Road" and the implementation of the "Culture Export" strategy, it is of great practical significance to sort out the cultural characteristics implied in the lacquer wares and study the traces of translation.

\section{The traces of translation of Chu lacquer wares}

\section{- Foreign research on the translation of Chu lacquer wares}

In the past decades, scholars from all over the world had been interested in lacquer wares. Foreign research on Chinese lacquer wares began in the early 20th century and was closely related to the relics of Chinese lacquer ware that flowed into Europe at that time. The first thing that attracted the attention of the academic circles was the lacquer ware of the Ming Dynasty. Scholar Fritz Low-Beer $(1936,1955)$ published a series of related research works, such as Carved Red Lacquer of the Ming Period and CHINESE LACQUER WARES. Since then, the research on cultural relics of lacquer wares of Ming and Qing Dynasties had sprung up, while some articles on the study of the Song and Yuan lacquer wares had appeared. In the last century, Lawton (1991) edited the results of a seminar held in Washington, DC, in 1990. Its contents included the development of Chu culture in art, archaeology and sinology. The book edited and published by Monika Kopplin (2002) demonstrated a comprehensive discussion of the historical background of lacquer arts in Asian regions such as China and the current development of lacquer craft and industry. It focuses on the historical inheritance and development of Chinese traditional lacquer ware and the culture and lacquer ware of the Yi ethnic group in China.

Nevertheless, the research on the translation of the cultural relics and texts originated from the Russian scholar Chistyakova, A.N $(2009,2011)$ who systematically studied the inscriptions from lacquer cup of the Western Han Dynasty excavated in Mongolia, and clarified the way of reading the Chinese characters in the bottom of the lacquer cup and its translation. Subsequently, the way of reading and translation was applied to the newly discovered lacquer cup inscriptions. Therefore, the scholar had established what the inscriptions should be included through the above research and confirmed the 
standardization of the components on the newly discovered lacquer cup inscriptions. This is also one of the few available results to make a combination of the cultural relics of lacquer wares and translations among foreign scholars.

With the rapid development of contemporary science and technology, many scholars in this century had adopted relevant professional techniques to carry out scientific research on cultural relics of lacquer wares. For example, Austrian scholar Wei Shuya (2011) applied X-ray technology to detect unknown components contained in the lacquer wares of the Warring States Period. In addition, there were many experts from the Japanese had done the research in this area. For instance, Japanese scholar Sung et al. (2016) analyzed and studied the culture and technology of lacquer wares in the Chinese historical period of Qin and Han dynasties.

\section{- Domestic research on the translation of Chu lacquer wares}

In the early 1950s, domestic research on Chinese lacquer wares started from the initial compilation of the atlas to the books on its culture and history. It was not until the end of the last century that relevant bilingual dictionaries related to the category of lacquer wares were published. The period of the research on lacquer wares was a long one, but scholars mainly focused on the history of lacquer wares or technical research. Since the beginning of this century, the attention to the lacquer wares of Chu has turned to the aesthetic aspects. Furthermore, scholars Hong Ying (洪樱 2004), Shen Jiaying (沈家英 2010), Wu Haiguang (吴海广 2010), Li Ke (李科 2012), Cheng Dan (程丹 2015) and Yu Jinggui (余 静贵 2016) all studied from the artistic aesthetics of Chu lacquer wares. It is believed that the color, sculpt, ornamentation and craftsmanship of Chu lacquer wares are the artistic symbols of aesthetics.

In recent years, the perspective of lacquer wares research has become more diversified, and the close relationship between Chu culture and lacquer wares has also received attention during this period. $\mathrm{Lv}$ Xiaowen (吕晓雯 2005) explored the influence of Chu culture on lacquer art from the aspects of geographical location, history and ideology. Chinese scholars Peng, W (2008) and Yang, SB (2009) analyzed the artistic image of Chu art and Chu culture and published academic papers at the 9th and 10th International Conference on Computer-Aided Industrial Design and Conceptual Design. Later, enough attention had been paid to the relations of Chu culture and Chu lacquer wares. Chinese scholar Liu Fangfang (刘芳芳 2013) discussed the impact of Chu culture and Chu people's thoughts on Chu lacquer wares and elaborated that the preference of red and black colors, the worship of phoenix and the diverse religious beliefs and the mania for witches have a profound influence on the art of lacquer.

In the past five years, the research on the translation of Chu lacquer wares has begun to attract some attention. Lan Caiyun (兰彩云 2013) took the texts of lacquer wares as an example to explore the translation strategies of Chinese culture-loaded words. This is also rare research for translation of texts of lacquer wares. Liu Ming (刘铭 2017) studied considered the English texts of the lacquer wares from three representative museums of Chu culture, and initially considered the methods of translation. Scholar Tan Dongrong (檀东榕 2017) explored the corresponding principles and methods in the exchanging culture of lacquer wares in Fujian region, emphasizing that the history and culture carried in the lacquer wares should be reflected in the translation.

According to the traces of translation, it is noticed that foreign studies generally tend to discover the new discoveries and problems through advanced scientific technologies in the research of lacquer 
wares. Nevertheless, there are only a few studies on the translation of the lacquer wares' texts within the specific historical period of Chu State. Additionally, domestic research began with the collection of lacquer wares. At the end of the 20th century, there were only sporadic studies. In the 21 st century, the research on lacquer wares began to increase. From the domestic traces of translation and the cultural characteristics of Chu lacquer wares, aesthetics research is more than cultural research while research on culture is beyond translation; foreign scholars tend to do technical level research while domestic scholars lay emphasis on a cultural connotation that is generally combined with other disciplines. In general, there is considerable amount research on Chu lacquer wares in aesthetics, industrial design, etc. Meanwhile, it is noted there are also a certain number of studies on the influence of Chu culture on Chu lacquer wares, but relatively few introductions and studies related to the translation of Chu lacquer wares.

\section{The cultural characteristics of Chu lacquer wares}

The sculpt, color and ornamentation of Chu lacquer wares are deeply influenced by Chu customs. Chu lacquer wares reflect the Chu people's ideology and culture. There are various viewpoints and descriptions about the cultural characteristics among scholars. However, based on the research findings from these scholars mentioned above, it is needed to summarize the cultural characteristics of these Chu lacquer wares. It is believed that there are four main characteristics making the most profound influence on the artworks of Chu lacquer wares:

- The first characteristic is the belief in sacrificial ceremonies and witchcraft showing with the irregular and mysterious sculptures.

There are considerable ancient Chinese works recorded on the belief. The words “灵氛” and “灵保” in The Songs of Chu are synonymous with witches. As a matter of fact, it is the Nine Songs that is a song to record of sacrificial ceremonies. It is said that: “楚人信巫鬼, 重淫祀 (Chu people believe in the witchcraft and ghost and take offering sacrifices to gods seriously)" from the chapter "Geography" of the History of the Han Dynasty. Wu Haiguang (吴海广 2010) suggested that

In the early period of the Chu State, the society was directly transformed from the primitive society which was filled with the original atmosphere of "witchcraft culture" and "sacrifices to gods". Thus, Chu people used to make up for the defects of knowledge by extraordinary imagination with the mysterious atmosphere in the spiritual life.

Therefore, there is a cultural tradition of holding witches, ghosts and gods in great account among Chu people who tend to follow the witchcraft culture which covers a variety of theories such as astronomy, geography, humanities, mathematics, medicine, divination and astrology. Under the influence of the belief, on the one hand, the images of witches and gods are drawn on the funeral utensils among a variety of the lacquer paintings; on the other hand, the sculptures of these Chu lacquer wares are unusual and out of the regular framework, such as the Chu lacquer wares "THE SHAPED CHIMERA (see Fig.1.)" : 


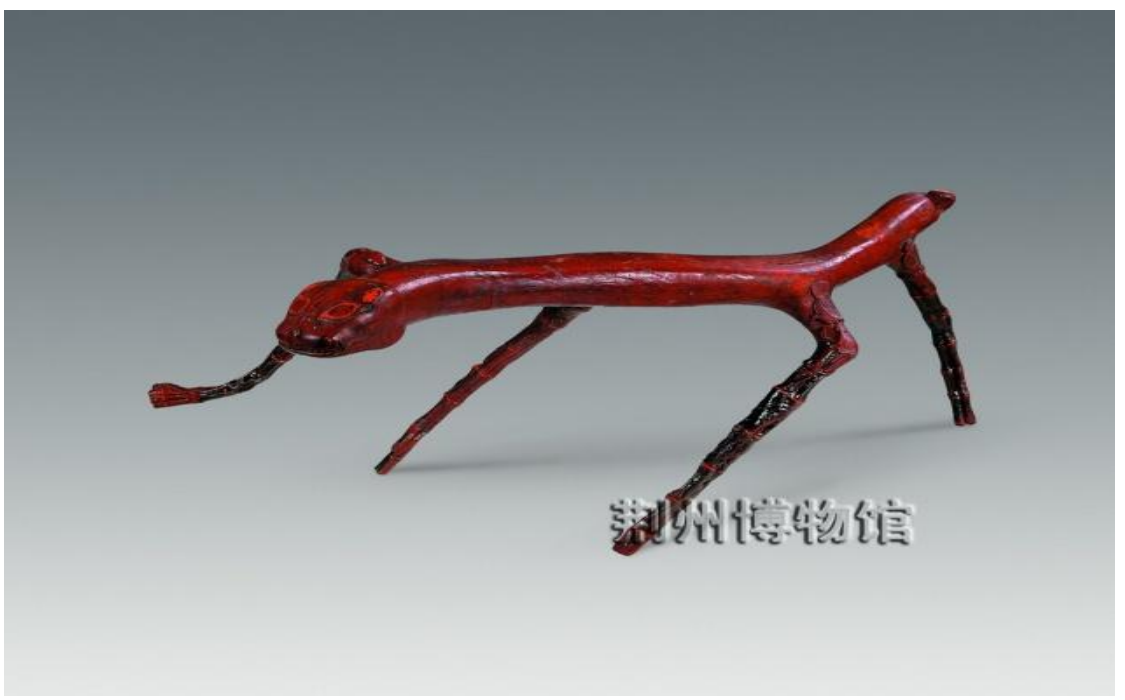

Fig.1. THE SHAPED CHIMERA (From the official website of Jingzhou Museum)

It was unearthed from the Tomb No.1 at Mashan, Jingzhou. Furthermore, it is from the Warring States Period (475-221B.C.) with $69.5 \mathrm{~cm}$ long and one of the earliest root carving artworks discovered in China. The root is shaped in tiger image while the length of four limbs is uneven, seeking the asymmetrical beauty through natural form of one tree root. The head is up and the mouth is open slightly. It is toothy, short-tailed and seems to be walking. Looking like bamboo joints, the two forelimbs are the right side of the trunk and the two hind limbs are the left side of the trunk with embossments of snake, snake biting lizard, lizard devouring bird or insects, etc. Combining several unrelated animal images and creating an amazing and fantastic lacquer ware is to demonstrate the imagination of Chu people and a certain religious and philosophical mystery.

- The second characteristic is the spirit of perseverance, innovation, and courageousness demonstrated with positive images.

In some ancient works, there are descriptions about the tough surroundings and unremitting efforts, like “䇢路蓝缕, 以启山林 (Endure great hardships in pioneer work)” from The Zuo Commentary; “楚虽三 户,亡秦必楚 (Rise up against violence and overthrow the rule of darkness)” from the chapter "Xiang Yu Biography" of the Shih Chi.

Among all of the lacquer wares, the exhibition “虎座鸟架鼓 (DRUM WITH PHOENIX STANDS) (see Fig.2.) " reflects the spirit:

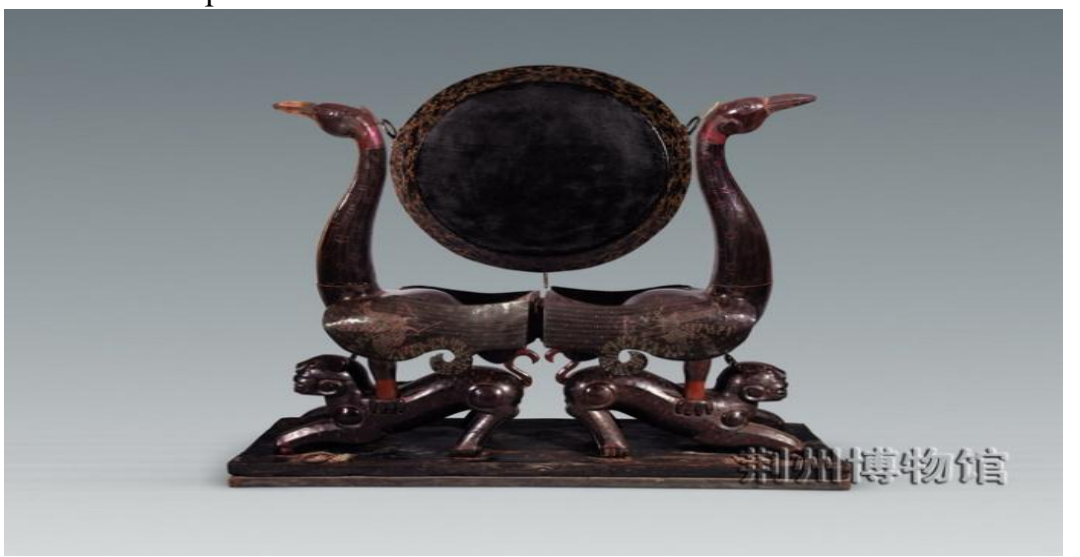

Fig.2. DRUM WITH PHOENIX STANDS (From the official website of Jingzhou Museum) 
DRUM WITH PHOENIX STANDS was unearthed from the tomb No. 2, Tianxingguan, Jingzhou with $149.5 \mathrm{~cm}$ height and $145.7 \mathrm{~cm}$ width. It is a primary musical instrument of the Chu State during the Warring States Period (475-221B.C.). Evidently, the squatting tigers are the base and two phoenixes seem to be singing songs proudly with heads up, enjoying their conquest on tigers by standing upright on each side of the tiger, and the big drum is hung in the middle of the two phoenixes. There are red, yellow and other colors to paint the tiger's stripes and phoenix feathers through the whole lacquer ware. The image of the squatting tigers and soaring phoenix show the peaceful consciousness and courageousness with a strong feature of Chu culture.

- The third characteristic is the color preference of red and black color.

Chu people admire the red color, while Chu lacquer wares are generally black and red as the main color. Furthermore, the combination of the two colors is a representative color assortment, full of Chu people's thought about the Heaven, Earth and original color concept, such as “鹗莺豆(LACQUER DOU-DISH IN MANDARIN DUCK SHAPE) (see Fig.3.) ".

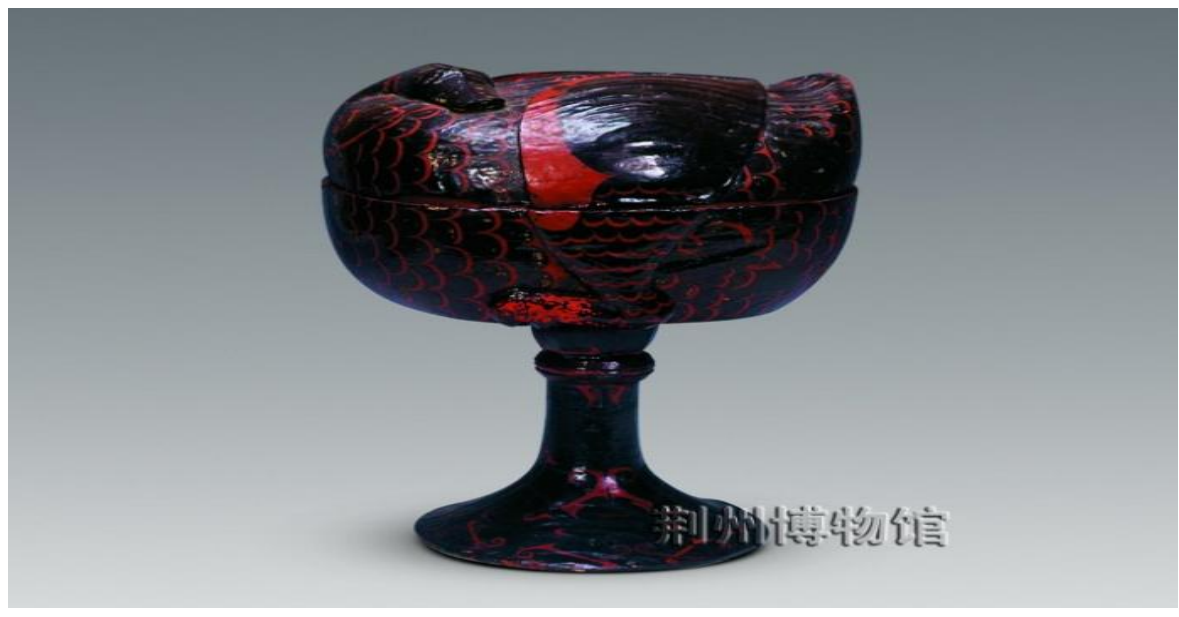

Fig.3. LACQUER DOU-DISH IN MANDARIN DUCK SHAPE (From the official website of Jingzhou Museum)

Unearthed from the tomb No.427, Yutaishan, Jingzhou with $25.5 \mathrm{~cm}$ height, the lacquer ware is a kind of utensil to ladle soup or dishes during the Warring States Period (475-221B.C.). The upper part is a lid and a plate while the nether part is a kind of handle, which is easy for servants to take dishes with them. As the plate is covered with the lid, the whole lacquer ware would develop into the shape of a mandarin duck. In addition, there is a golden phoenix respectively painted on both sides of the tail of the mandarin duck. From its manner of posture, it has an air of calm, leisurely and comfortable. Indeed, it's a rare piece of art. Most importantly, it is easy to see that it is painted with the color of black while the feathers are painted in red and gold. With some exceptions, there is almost red and black color among these Chu lacquer wares.

- The fourth characteristic is the ornamentation preference of phoenix and dragon pattern.

Chu people give priority to phoenix which has been occupying a dominant position. Since the image of dragon is influenced by the Central Plains culture, it is visible that the ornamentation preference of dragon pattern is in a supporting role, such as the lacquer wares “彩绘凤鸟纹耳杯(LACQUER EAR-CUP WITH PAINTED DESIGN OF PHOENIXES) (Fig.4.)”. 


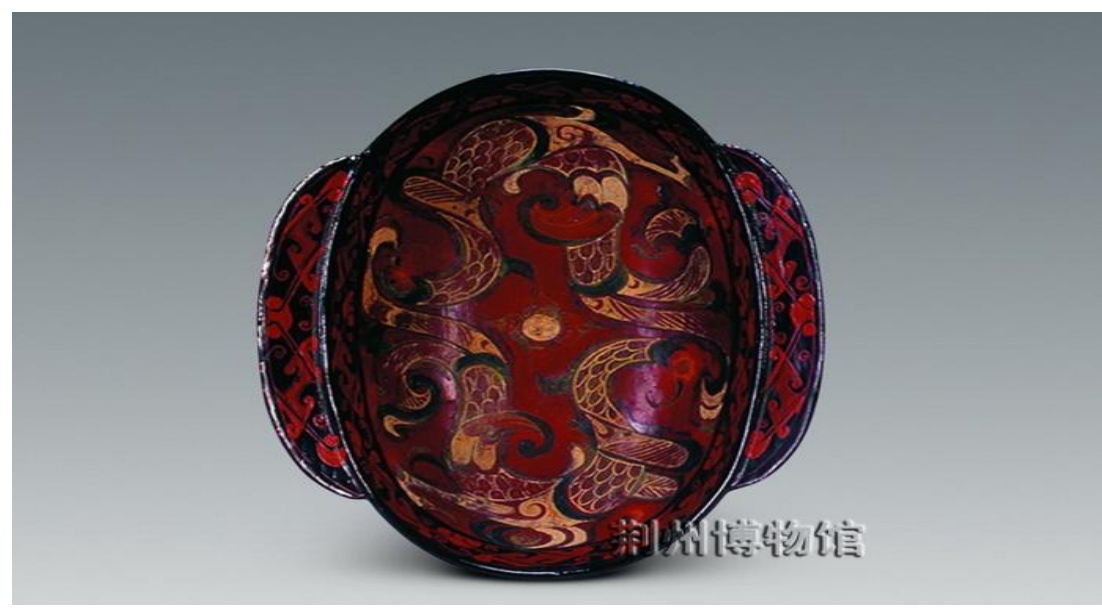

Fig.4. LACQUER EAR-CUP WITH PAINTED DESIGN OF PHOENIXES (From the official website of Jingzhou Museum)

Unearthed from the tomb No.1, Mashan, Jingzhou with $15.5 \times 5 \mathrm{~cm}$ caliber size and $4.5 \mathrm{~cm}$ height, the ear cup is a vessel used for drinking during the Warring States Period (475-221B.C.). Because the shape of the vessel is elliptical, shallow and flat, with half-moon ears on both sides, in other words, there is an ear-like handle on both sides for the drinker to hold, it is called the ear cup. Generally, the surface and inner side around the edge are darkly painted while the inside area with dark red paint. It is noticed that there are drawings with a painted design of transmuted phoenixes along the inner side around the edge, the surface of "the ears" and the outer side. The base is decorated with silver powder to depict the double phoenix that is connected end to end. Thus, as a drinking vessel, the function is convenient, the appearance is appealing and the ornamentation of transmuted phoenixes is impressive, splendid and mysterious.

\section{Translation and cultural characteristics}

The role of translation on cultural factors is often generalized to promote cultural exchanges. As a matter of fact, translating plays a significant role in language transformation, information transmission and aesthetic reproduction.

Translating as an activity and translation as the result of this activity are inseparable from the concept of culture. The translational capacity of culture is an important criterion of culture's specificity. Culture operates largely through translational activity since only by the inclusion of new texts into culture can the culture undergo innovation as well as perceive its specificity (Peeter Torop 2002:593).

During the translation process, translation refers to factors between different languages as well as cultures. Translation, whether as an activity proper, a process or a product, carries certain cultural meaning. Possibility, forms and contents of translation depend on various factors of the target culture. Translation results not only enrich the national culture but also reflect cultural change and development in a way (Yang Shizhang 杨仕章 2001:15).

The cultural characteristics of Chu lacquer wares are an integral part of Chu culture. Thus, the evolution, usage and expression way of translation is inevitably influenced and restricted by their cultural characteristics. When discussing the strategies and standards of translation, it is needed to 
consider the main cultural characteristics of the lacquer wares. Meanwhile, it is also advisable to attach importance to the contemporary sociocultural factors of the lacquer wares. Moreover, the keynote of Chu culture is romanticism which is represented by the great works of The Songs of Chu filled with rich imagination and earnest emotions. The tomb guardian sculptures from the Chu lacquer wares reflect that trait from the sculpt of upward and unfolding antler. In addition, geographical location, social revolution and ideological changes are factors that cannot be ignored in the translation process. To convey the social and cultural background covered by the language, it is acceptable to understand that the identical words in a cross-cultural environment can produce multiple meanings, or different words can have similar meanings, thus, it is possible to be faithful original translation.

\section{Conclusion}

The cultural characteristics of Chu lacquer wares are closely related to translation which is an effective way to exchanging cultures. Chu lacquer wares are the classic representatives of Chu culture and there are four main cultural characteristics among these Chu lacquer wares: the belief in sacrificial ceremonies and witchcraft showing with the irregular and mysterious sculptures; the ornamentation preference of phoenix and dragon pattern; the spirit of perseverance, innovation, and courageousness demonstrated with positive images and the color preference of red and black color. Generally, translated texts are an indispensable tool for learners studying and learning Chu culture and lacquer wares and tourists visiting the regions of Chu culture. It is noted that take cultural characteristics and factors within Chu lacquer wares in the account during translation process in order to make it possible to deeply exchange of glorious Chu culture through various languages.

\section{Acknowledgements}

This work was supported by the Humanities and Social Sciences Research Program of Hubei Provincial Department of Education of China under Grant No.19G126.

\section{References}

[1]. Chistyakova, A.N. 2009. CHINESE INSCRIPTION ON THE LACQUER CUP FROM NOIN ULA MOUND 20 (MONGOLIA). Archaeology, Ethnology and Anthropology of Eurasia, 37(3):59-68.

[2]. Chistyakova, A.N. 2011. LACQUER CUPS OF THE WESTERN HAN DYNASTY (NOIN ULA, MONGOLIA): AN ANALYSIS OF INSCRIPTIONS. Archaeology, Ethnology and Anthropology of Eurasia, 39(4):83-89.

[3]. Fritz Low-Beer. 1955. CHINESE LACQUER WARES. East and West, 5(4):285-290.

[4]. Lawton, Thomas., Ed. 1991. New perspectives on Chu culture during the Eastern Zhou Period. Princeton University Press.

[5]. Meesook Sung, Jaekook Jung, Rong Lu and Tetsuo Miyakoshi. 2016. Study of historical Chinese lacquer culture and technology-Analysis of Chinese Qin-Han dynasty lacquerware. Journal of Cultural Heritage, 21:889-893.

[6]. Maenchen-Helfen, FL Beer. 1936. Carved Red Lacquer of the Ming Period. Burlington Magazine for Connoisseurs, 69 (403):166-172.

[7]. Peeter Torop. 2002. Translation as translating as culture. Sign Systems Studies, 30 (02):593-604.

[8]. Peng, W. 2008. The Analysis to the Chu-Art in the International Cultural Vision. 9TH INTERNATIONAL CONFERENCE ON COMPUTER-AIDED INDUSTRIAL DESIGN \& CONCEPTUAL DESIGN, VOLS 1 AND 2, 1149-1153. 
[9]. Shuya Wei, Valentina Pintus, Václav Pitthard, Manfred Schreiner and Guoding Song. 2011. Analytical characterization of lacquer objects excavated from a Chu tomb in China. Journal of Archaeological Science, 38(10): 2667-2674.

[10]. Yang, SB. 2009. Sorcery, Taoism, Polytheism, Sao-Sources of Chu Art's Spiritual Images. 2009 IEEE 10TH INTERNATIONAL CONFERENCE ON COMPUTER-AIDED INDUSTRIAL DESIGN \& CONCEPTUAL DESIGN, VOLS 1-3: E-BUSINESS, CREATIVE DESIGN, MANUFACTURING - CAID\&CD'2009, 1672-1675.

[11]. Kopplin, M., Ed. 2002. Lacquerware in Asia, Today and Yesterday. United Nations Educational, Scientific and Cultural Organization.

[12]. Zeng, J \& Tian, C. 2016. Translating the Three Kingdoms Cultural Attractions in Jingzhou and Xiangyang: Problems and Solutions. IRA International Journal of Education and Multidisciplinary Studies 5(2), 94-113.

[13]. 程丹. 2015. 楚漆器艺术的审美意蕴. 艺术百家, S2: 79-81.

[14]. 洪樱. 2004. 战国时期楚国漆器的审美解读. 民族艺术研究, 1: 77-80.

[15]. 兰彩云. 2013. 目的论指导下的汉文化负载词英译策略探讨. 对外经济贸易大学硕士论文.

[16]. 李科. 2012. 略论楚漆器的色彩特征与审美意识. 社会科学家, S1: 255-256.

[17]. 刘芳芳. 2013. 试析楚人的思想对漆器的主要影响. 苏州科技学院学报(社会科学版), 30(5): 65-69.

[18]. 刘铭. 2017. 博物馆解说词英译方法与策略研究——楚文化代表文物为例. 长江大学硕士论文.

[19]. 吕晓雯. 2005. 浅析楚文化对漆器艺术的影响. 南京艺术学院学报: 美术与设计版, 3: 123,128.

[20]. 沈家英. 2010. 楚漆器纹样的审美特色与当代启示意义. 文艺评论, 4: 94-96.

[21]. 檀东榕. 2017. 论海丝漆器文化翻译中的原则与方法. 旅游纵览(下半月), 11 .

[22]. 吴海广. 2010. 楚漆器艺术的审美意蕴. 湖北社会科学, 12: 196-198.

[23]. 杨仕章. 2001. 略论翻译与文化的关系. 解放军外国语学院学报, 24(2): 15-19.

[24]. 余静贵. 2016. 论先秦楚漆器符号的审美意味. 中华文化论坛, 9: 34-41. 